\title{
大規模河川の河口から放出される 土砂の海底への沈降と堆積過程の計算 一大河津分水路の河口を対象として- NUMERICAL STUDY OF SETTLING AND TRANSPORT OF SEDIMENT DISCHARGED FROM LARGE RIVER MOUTH - AN APPLICATION TO THE OKOZU RIVER MOUTH -
}

\author{
大竹剛史 $1 \cdot$ AYURZANA BADARCH ${ }^{2}$ 細山田得三 3
}

Takeshi OTAKE, Ayuruzana BADARCH and Tokuzo HOSOYAMADA

\author{
1学生会員 長岡技術科学大学大学院 工学研究科 建設工学専攻（干940-2188 新潟県長岡市上富岡町1603-1） \\ 2非会員 工修 長岡技術科学大学大学院 工学研究科博士課程 エネルギー環境工学専攻 \\ 3 正会員 工博 長岡技術科学大学 環境社会基盤工学 教授
}

\begin{abstract}
Estuaries of the large river discharge river waters and sediment to the sea. The discharged sediment is mainly the wash load, which is affected by density currents, tide, inertia forces of river discharge. Sediment which has repulsive force in pure water, lost electrical charge when it meets sea water and finally made flocculation caused by molecular attractive force. To understand distribution of the sediment in sea bottom, above mentioned phenomena should be included in numerical simulation algorithm for sediment transport model. In this study, a numerical algorithm for sediment particle transport under the effects of flocculation is originated. The algorithm is mainly based on the Lagrangian method. The performance of the numerical method is confirmed by the Lock-exchange flow in laboratory scale case. Application of the method to field scale calculation is conducted for the Okozu diversion channel in the Shinano River mouth. Settling of the sediment through the pycnocline is visualized with high resolution.
\end{abstract}

Key Words : Sediment transport, River mouth, Density current, Salt wedge

\section{1. はじめに}

海岸浸食が顕著な日本海側の海岸線において，信濃川 の下流部（新潟県）に本川をショートカットして人工的 に開削された大河津分水路の河口は，分水路によって供 給される土砂が豊富であり, 河口周囲に海岸線が前進し ている区域が目立っている（図-1）。大河津分水路は通 水後約 90 年を経過しており, その間の汀線前進を引き起 こす重要な供給源となっている. 日本海側の海岸は, い ずれも冬期には季節風による日本海特有の冬期風浪が来 襲し，春期には融雪出水，夏期には梅雨および台風によ る大規模な出水が生じる，という季節的なサイクルが明 瞭である.

出水時に河口から放出された土砂は, 粒径の大きさに 依存しながら海水と混合しつつ, 細かい土粒子は沖一輸 送され，最終的には未固結土砂として海底に沈降する. 粗い土粒子は早く沈降し, 河口周辺にとどまり, 河口テ ラスを形成する，その後，一部は冬季風浪によって岸方 向に輸送され河口周辺の土地の形成に寄与寸るものと見 られている.

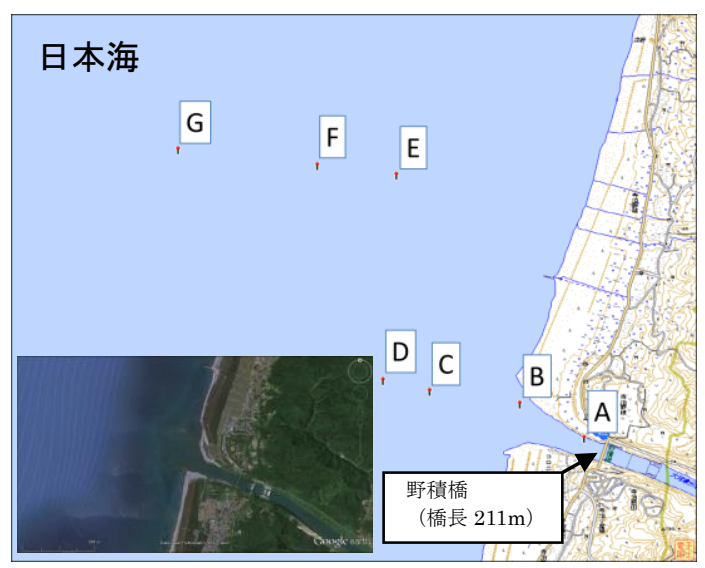

図-1 大河津分水路河口での各種鉛直分布測定

河口の土砂が長い年月を経てどの様に地形を形成して いくかを調べることは興味深い. 関口ら ${ }^{1)}$ は河川供給土砂 が重要な役割をはたしてきた大河津分水一寺泊野積海岸 システムを取り上げ，堆積環境の調查を行っており，外 海に面する沖浜海底に, 洪水流由来の泥質堆積物が保存 されることが得られている. 

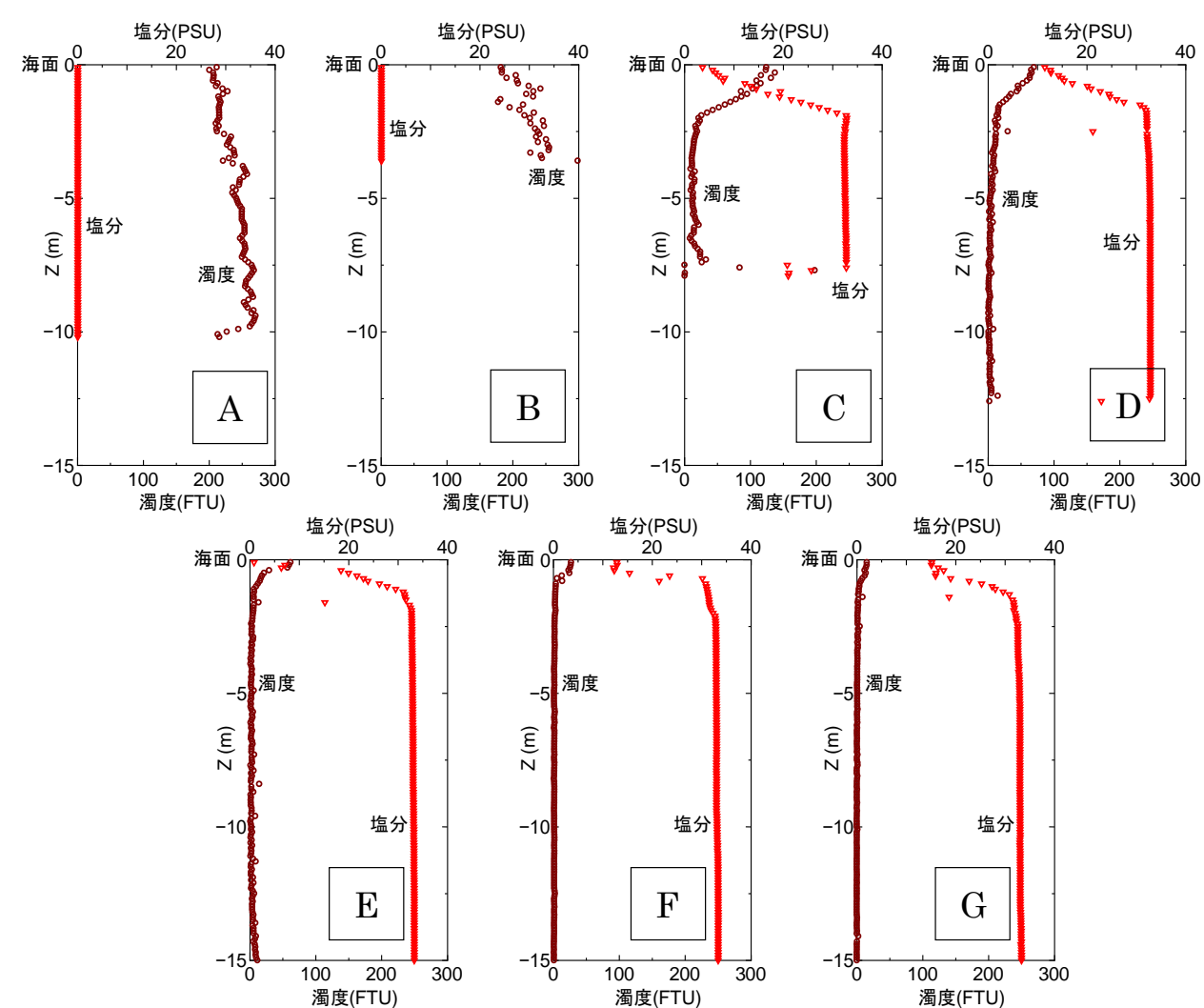

図-2 各測定点での塩水濃度 $(\mathrm{psu})$ と濁度(FTU)

河口は, 河川水によって土砂・シルトが流入する一方, 海岸からは潮汐や波浪によって塩水や漂砂が河口に輸送 され, 浮遊土砂が複雑に混合される場所となっている. 著者らの研究グループでは過去に密度流によって生じる 上昇流により海底付近の浮遊砂が塩水楔の影響を受ける 可能性を示唆しており, 河川からの土砂輸送の動態把握 に対して密度流を考慮する必要があると考えられる2).さ らに, 河川から輸送されてきた土砂は, 塩水と接触する ことによって電荷およびそれに起因する反発力を失い, 分子間力によって凝集し，フロックを形成して沈降する 速度が速まることが知られている3．宋ら ${ }^{4}$ は, 移流・拡 散方程式を用いて河口域における密度流と浮遊土砂の数 值計算を実施しているが，オイラー的手法のため塩水に 接触した履歴を記憶しながら土砂が沈降するモデルとは なっていない，そこで本研究では，大河津分水路河口に おける堆積土砂の生成過程に対して, 密度流や凝集を考 慮した土砂輸送の数值計算法の提案を目的とする. 特に 土砂輸送過程については，沈降速度を考慮した移流・拡 散方程式と平行して粒子追跡計算を実施して海底一の沈 降過程について考察を行った.

\section{2. 研究対象の調査状況}

計算対象である大河津分水路河口において, 近年で は平成 23 年 7 月に新潟・福島豪雨による大出水が生じて いる. この際に大量の土砂が河口から放出され，国土交 通省北陸地方整備局信濃川河川事務所では, その詳細な
地形を調査するためにナローマルチビームによる海底地 形測量を実施している。.また，関口らは，バイブロコア サンプリングによる海底土質の鋁直分布構造の取得及び 塩水濃度, 濁度, ADCP による流速測定を実施している.

図-1 は関口らによって計測された海水の濁度, 塩分濃度 の鉛直分布の測定箇所(A-G 点)であり，図-2 はその測定 結果である. 最も岸側（A 点）および B 点においては全 層に渡って全く塩分が検出されず，濁度は高濃度となっ ている. 濁度は下層部に向かって上昇する傾向を示して おり，粒径の大きな粒子が沈降したためと見られる．C 点の結果では, 海面から $2 \mathrm{~m}$ 付近から下方が海水となって おり, それと同時に濁度が急激に減少していることが分 かる. また $2 \mathrm{~m}$ よりも海面に近いところでは, 塩分の減少 とともに濁度が上昇している. この傾向は D 点において も確認され, さらに沖側の $\mathrm{E}, \mathrm{F}, \mathrm{G}$ 点においても確認され る. また，底面に近いところの濁度は海水中であっても 高い值を取る傾向があることを C, D, E点において確認で きる.これは，沈降した土砂が海底に堆積しつつある状 況と考えられる. 以上の観測結果より, 河口付近では全 層が河川水であり，土砂を含んでいるが，それが沖側一 流れ出て海水と接触することによって沈降が促進され, 底面に高濃度の未固結土砂を浮遊させている状況が推測 できる. 本研究ではこれらの流動, 土砂・塩分の移流・ 拡散, 土砂の海水によるフロック化と沈降の促進に関す る数值モデルを作成した. 特に浮遊粒子 1 つ 1 つの動き をラグランジュ的に追跡することによって粒子個別の属 性を評価するモデルとした。 


\section{3. 数値計算手法}

\section{(1) 土砂輸送の基礎方程式}

本研究では土砂輸送の計算を以下に示す 2 種類の方法 を用いて行った.

\section{a）移流拡散方程式による土砂の計算}

式(1)に示す移流拡散方程式を用いて土砂濃度の空間分 布の時間発展を求めた.

$$
\frac{\partial c}{\partial t}+u \frac{\partial c}{\partial x}+\left(w-w_{s}\right) \frac{\partial c}{\partial z}=D \nabla^{2} c
$$

ここに $t, x, z, u, w, c, D, w s$ は，時間，水平座標，鉛直座 標，水平流速，鉛直流速，土砂濃度，土砂の拡散係数， 土砂の沈降速度である. 土砂濃度は, 河口付近の平均的 な土砂を 1 とし, 海側に流出することによって希釈され て1よりも小さくなることを想定している，ただし，底 面では高濃度になるため 1 を超えることが生じる可能性 はある. 土砂の拡散係数は後述する乱流モデルによって 計算される乱流拡散係数を与えた. 沈降速度 ws は土砂の 鉛直下方への輸送を決める重要な量であり, 過去から数 多くの研究が行われている5) ${ }^{5}$. 従来の研究では $w_{s}$ にスト 一クスの沈降速度を与えることが一般的と思われる. ス トークスの沈降速度は土粒子の最終沈降速度であり, 抵 抗力と浮力と重力のバランスによって決定される. 水中 では最終沈降速度に至るまでの時間が十分短いことが理 論的に確認され，その值を使用することの妥当性は理解 される. しかしながら, 移流拡散方程式はオイラー的な 解析法であり，粒子を追跡しないことを前提としている ため, 粒子の履歴に応じた沈降速度を考慮できないとい う問題がある. 具体的な与え方については後述する.

\section{b）粒子追跡計算による土砂の計算}

この方法では土砂を連続量としてではなく個別な粒子 として捉え, 粒子位置の時間発展を追跡していく.この 方法の利点は, 粒子の状況を個別的に処理することがで きるため, 例えば $1 つ 1 つ の$ 粒子の粒径変化やその粒子 が接触した塩分の量, それに伴う粒径の変化，さらに粒 子ごとの沈降速度の変化をモデル化して時々刻々追うこ とが容易である。

粒子の移動速度は，粒子を球体と考え式(2)のような運 動方程式を解く.

$$
\frac{4}{3} \pi r^{3} \rho_{\text {sed }} \frac{d \mathbf{V}_{\mathbf{b}}}{d t}=\mathbf{F}_{r}
$$

ここに $\mathbf{V}_{\mathrm{b}}, r, \rho_{\mathrm{sed}}, \mathbf{F r}$ はそれぞれ土粒子の移動速度，土粒 子の半径，土粒子の密度，土粒子が流体から受ける抵抗 力である. 抵抗力土粒子の粒径および初期配置は正規分 布および一様分布に従う乱数を発生させて求めた。抵抗 力 Frは以下のように表わされる.

$$
\mathbf{F}_{r}=\frac{1}{2} \rho_{w} C_{D} \mathbf{u}_{\mathbf{r}}\left|\mathbf{u}_{\mathbf{r}}\right| A
$$

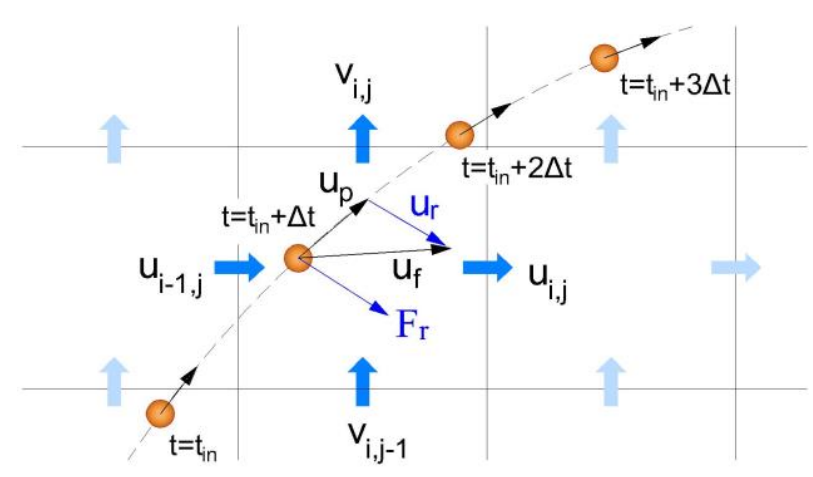

図-3 計算格子と粒子追跡の計算の説明図

ここに， $\rho_{w}$ は流体の密度， $C_{D}$ は抗力係数，A は粒子の 投影面積である．ur は粒子の相対移動速度であり，流体 の速度 $\mathbf{u}_{\mathbf{f}}$ から粒子速度 $\mathbf{u}_{\mathbf{p}}$ を差し引いた速度である。ま た， $\mathbf{F}_{\mathbf{r}}$ は $\mathbf{u}_{\mathbf{r}}$ と平行である(図-3). 抗力係数はレイノルズ 数 $(\mathrm{Re})$ の関数であり,一般的に使われている実験によるグ ラフから数值計算に利用できる関数として近似的に表示 して幅広い Re に対して計算できるようにした.このため, 一般的には層流の範囲で計算される $C_{D}$ を乱流でも計算で きるように拡張している. 粒子の沈降速度については先 の考察から最終沈降速度に至るまでの時間が十分に短い と考えて，式(2)で計算された鉛直方向の粒子速度に下向 き沈降速度を付加することによって考慮した。

\section{c）基準沈降速度}

土砂の沈降速度はその海底への堆積過程を議論する上 で最も重要な量である．鶴谷らは，海底の泥質を形成す るような微細懸濁物質の場合，沈降速度の最大值は $0.258 \mathrm{~cm} / \mathrm{s}$ としており 7$)$, ストークスの沈降速度とした場 合の粒径は $55 \mu \mathrm{m}$ である. このため, 最小粒径をその 5 分の 1 程度の $10 \mu \mathrm{m}$, 中央粒径を $32 \mu \mathrm{m}$ とし, 中央值に 対応したストークスの沈降速度 $0.09 \mathrm{~cm} / \mathrm{s}$ を基準とした計 算を行った.

\section{（2）密度流の基礎方程式}

密度流の運動は，式(4)に示すブシネスク近似を用いた ナビエストークス方程式(NS 方程式)および式(5)に示す非 圧縮性流体の連続式を連立させて解くことができる.

$$
\begin{aligned}
& \frac{\partial u_{i}}{\partial t}+u_{m} \frac{\partial u_{i}}{\partial x_{m}}= \\
& -\left(1+\frac{\Delta \rho}{\bar{\rho}}\right) g \delta_{i 3}-\frac{1}{\bar{\rho}} \frac{\partial p}{\partial x_{i}}+v_{t} \nabla^{2} u_{i} \\
& \frac{\partial u_{i}}{\partial x_{i}}=0
\end{aligned}
$$

ここに $u_{i}, t, x_{i}, g, \bar{\rho}, \Delta \rho, p, v_{t}$ はそれぞれ, 流速ベクトルの i成分, 時間, 空間座標, 重力加速度, 淡水の密度, 密度 偏差, 圧力, 渦動粘性係数である. 式(4),(5)を連立させて 解く方法は非圧縮性流体の計算法として確立されている 


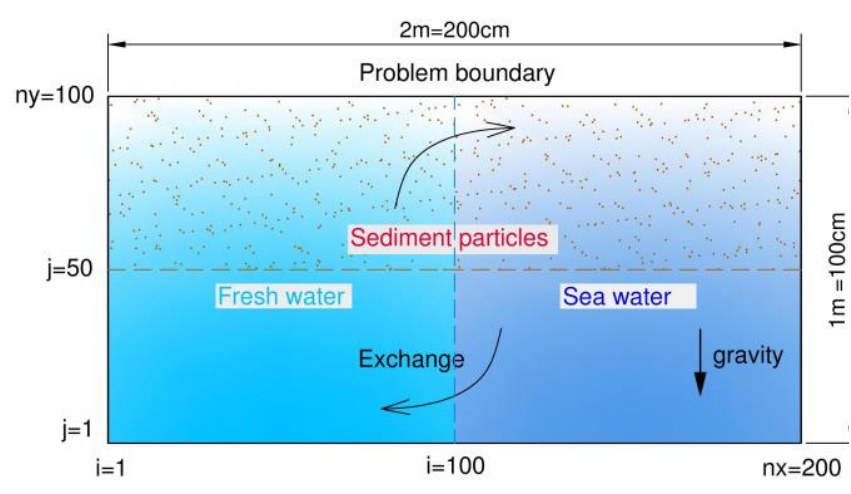

図-4 室内実験スケール(ロックイクスチェンジ)の計算領域 反復計算による流速・圧力同時緩和アルゴリズムを用い た ${ }^{8)}$.

実現場スケールでは，計算対象領域の水平スケールに 対して鉛直スケールが十分に短いためNS方程式に静水圧 近似を用いて計算した. すなわち鉛直方向の運動方程式 が簡略化されて静水圧を計算し，連続条件式(5)を満足す るように鉛直流速を決定した。この方法では反復計算を 実施する必要はないため高速化されるが，鉛直方向の加 速度運動が考慮されないという久点を有している.

密度偏差の時間発展は式(6)に示寸密度偏差の移流拡散 方程式を用いて計算した。流速值 $u_{m}$ はNS方程式によって 求められた值を用いている. 密度偏差の主要な原因は水 温およひ塩分であり，本来ならばそれらを計算して状態 方程式から密度偏差を求めることが本筋であるが, 温度 を考慮するような長時間の計算は行わなかったので密度 と塩分の移流拡散方程式と同等と考えて式(6)を用いた.

$$
\frac{\partial \Delta \rho}{\partial t}+u_{m} \frac{\partial \Delta \rho}{\partial x_{m}}=A \nabla^{2} \Delta \rho
$$

式中の $A$ は渦動拡散係数であり, 以下に述べる乱流の 取り扱いから算出される值を用いた。

\section{（3）乱流の取り扱い}

本計算では，乱流モデルとして LES(Large Eddy Simulation)を用いた. 池畑ら ${ }^{9}$ は非等方型スマゴリンスキ 一・モデルに基づいて LES を行い，負の浮力効果を取り 入れたモデルを構築しており，計算に取り入れた。格子 スケール $\Delta l$ やスマゴリンスキー定数 $C_{s}$, ひずみ速度テン ソル $S_{i j}$ などを用いて乱流粘性係数 $\nu_{t}$ を以下のように表わ した.

$$
\left.\begin{array}{l}
v_{t}=\left(c_{s} \Delta l\right)^{2} \sqrt{2 S_{i j} S_{i j}\left(1-\frac{R_{i}}{P_{r}}\right)}, \quad R_{i}=\frac{-\frac{g}{\rho_{w}} \frac{\partial \Delta \rho}{\partial z}}{2 S_{i j} S_{i j}} \\
S_{i j}=\left(\frac{\partial u_{i}}{\partial x_{j}}+\frac{\partial u_{j}}{\partial x_{i}}\right), \quad \Delta l=\sqrt[3]{\Delta x \Delta y}
\end{array}\right\}
$$

$R i$ は局所的に定義されるリチャードソン数であり,この

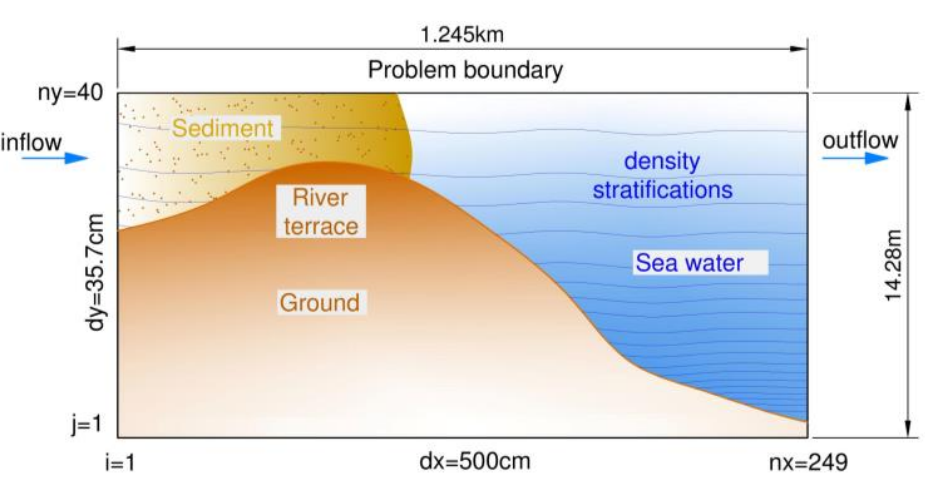

図-5 大河津分水路河口を対象とした計算領域（模式図）

值が大きいほど安定であり，乱流の影響が小さくなるこ とを示している. Pr はプラントル数であり，式(7)の第一 式は $\operatorname{Pr}=1$ の場合, $R i$ が 1 で乱流粘性係数がゼロとなる.

\section{(4) 計算領域}

本研究では，粒子追跡による計算においてフロックの 形成を模した粒子サイズを計算の途中で変更するスキー ムを導入している。この効果を確認することを目的とし て室内実験スケールでの粒子の挙動を調べた．次いで大 河津分水路河口の地形形状に対して前途の考察に基づい て浅水系の方程式を適用して計算を行なった.

室内実験スケールの現象にはロックイクスチェンジを 対象とした. ロックイクスチェンジとは, 矩形容器の左 右で密度の異なる流体を入れ，中央のしきりを瞬間的に 外すと密度の低い流体が上層へ, 密度の高い流体が下層 へと進行する現象である. 初期状態は容器の上層に土粒 子を配置した. 水平方向の長さ $200 \mathrm{~cm}$, 鉛直方向の長さ $100 \mathrm{~cm}$ の領域で 20 秒間分の計算を行った(図-4).

フロックの形成モデルは，土粒子が塩水に触れている 時間と塩分濃度を累積し，それに応じて粒径を増やすモ デルを導入した. $2 \%$ 塩水に土粒子が 10 秒間触れてい ると, シグモイド関数に従い最終的には 2 倍の大きさに まで増大するモデルとした.

実現場スケールでは，大河津分水路河口の標高データ を，河川の横断方向に平均を取り断面 2 次元の地形デー タを作製した. 水方向の長さ $1.245 \mathrm{~km}$, 鉛直方向の長さ $14.28 \mathrm{~m}$ の領域で 10 時間分の計算を行った(図-5). フロッ クの形成モデルは，室内実験スケールのフロック形成モ デルと同様に，2\%の塩水に土粒子が 300 秒間触れている と，シグモイド関数に従い最終的には 2 倍の大きさにま で増大するモデルとした ${ }^{3)}$.

\section{4. 数値計算結果}

オイラー的な手法である移流拡散方程式を用いた方法 と比べると，ラグランジュ的手法である粒子追跡の方法 は，粒子ごとの特徵を個別に計算して保存できるためフ ロックの形成過程を表現することができる. 具体的には, 


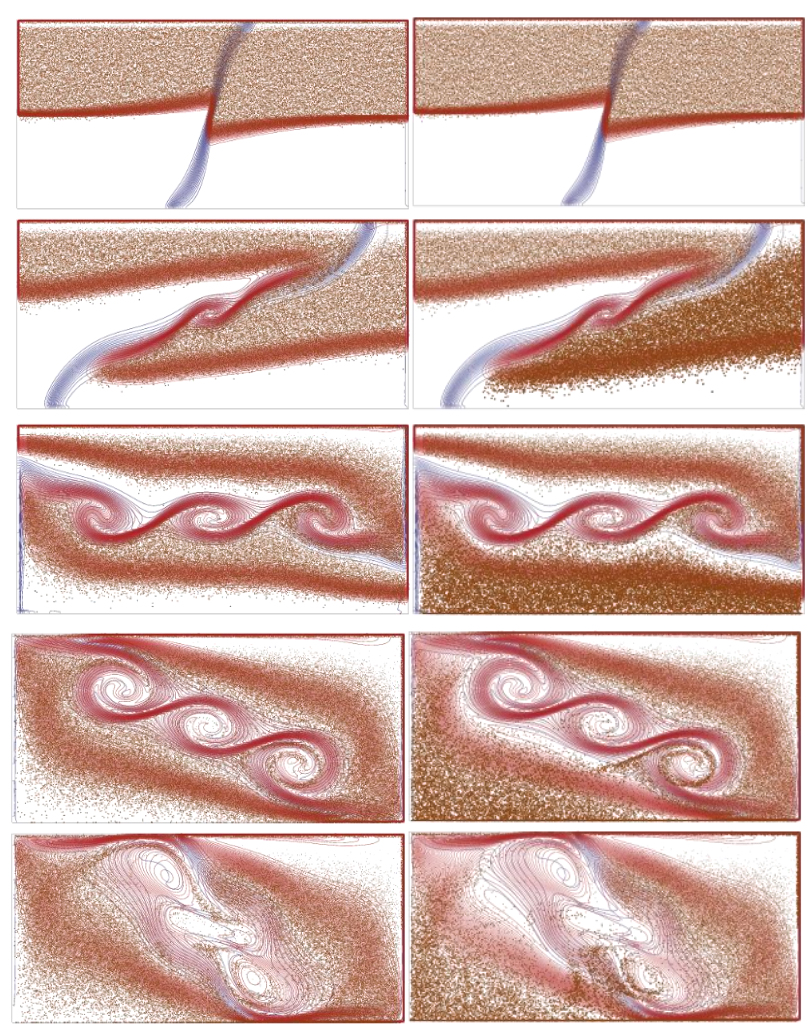

図-6 ロックイクスチェンジでの土砂濃度, 密度, 土砂粒子 の計算結果 (20 秒間)

\section{最上段は 2 秒目，以下 4 秒間隔}

左段 : フロック化なし，右段 : フロック化あり

土粒子が塩水に触れている時間と塩分濃度を累積し，そ れに応じて粒子の密度を増やすモデルを考案した，そこ で本研究では室内実験スケールを対象とした計算を行い 粒子追跡の方法の妥当性を検証し, その後, 実現場ス ケールを対象とした計算を行い現場への適用性について 考察する.

\section{(1) 室内実験スケール}

図-6には図-4を初期条件としたロックイクスチェンジ による土砂濃度 (等高線赤), 密度 (等高線青) , と土砂 粒子（茶色点）の時間発展状況を示す. 右段はフロック 化による粒径の増大が考慮されており, 左段はフロック 化が考慮されていない. フロック化のモデルは, 仮想的に $2 \%$ の密度に 10 秒触れると 2 倍に粒径が増大寸ると設定し た. 右段・左段とも 8 秒後には淡水と塩水の境界での強 いせん断力によるケルビン・ヘルムホルツ不安定によっ て渦が発生しており, 土粒子は渦により巻き上げられて いることを確認できる．左段は概数土砂濃度の高い部分 に土粒子が配置されている. 右段では土粒子は塩水に触 れている部分（初期に右側で上側に配置された粒子）の 粒子サイズが増大し, 沈降速度が上昇しており, 凝集モ デルなしの場合に比べて鉛直方向に土粒子が広がりを持 って分布している. 一番下の右段には一旦沈降した土粒 子が渦によって巻き上がっている様子が示されている.

\section{(2) 大河津分水路への適用例}

図-7 は浅水型の計算方法を大河津分水路の海底地形に 対して適用した結果である. 沈降速度 ws と粒径 Dを変化 させた 3 ケースに対応したものである. コンターライン および土粒子の值は図-6 と同様である. 計算時間は 10 時間であり、左側の流入境界（河川上流方向）から右側 （沖側）の流出境界に向かって河川流が流れている. 土 粒子の初期分布は河口テラスより上流側の計算格子寸心゙ てに 1 格子当たり 100 個の土粒子をランダムに分布させ て計算したものである．計算に用いた粒子数の合計は 98200 個であり, 計算実行時間は粒子追跡を入れた場合と 入れない場合で約 9.8 倍となった. コンターラインが密に なっている部分は空間方向の変化が顕著であることを示 している.

図-7 の最上段では河川水が海水上に乗り上げるところ で土砂が鉛直上方向に押上げられて巻き上がっているこ とがわかる. 密度躍層付近で波動状の変動も見られ，こ れは計算初期の変動とみられる. その後の時間では減衰 し密度場はほぼ定常に近い状態である. 土砂濃度と土砂 粒子の動きは, 3 ケースの違いに対応しており、粒径・沈 降速度が一番大きい左段では土砂は急速に沈降し, 河口 テラスよりもやや沖側の海底に着底している. 中段のケ 一スでは粒径が小さくそのため沈降が遅れているが 5 時 間経過した後は左段と同様の分布となる. 右段は粒径を かなり小さくしたケースであり、粒子が浮遊状態を長く 継続し, 密度躍層の下部で流れによって沖側に輸送され ながら急激に沈降している.この現象は図-2のCに見ら れる, 海水の接触と濁度の減少に対応していると思われ る. このような土砂が最も沖に運ばれ海底における未固 結土砂を形成しているものと考えられる.

\section{5. まとめ}

粒子追跡を行う方法では, 粒子個別にレイノルズ数や 抗力係数を設定でき, フロックの形成過程を表現するこ とが容易である.これにより土砂輸送解析の新しい方向 性を示した. 土砂の流出は洪水などの大出水時が顕著で あるが，この時の大出水時の土砂輸送の現状については 観測の危険性を考慮すれば不可能に近いと考えられる. 本研究では大河津分水路の渴水時に近い流量（夏季には 長時間このような状況が継続する）に対する考察にとど まっている. 本研究は内部流速場を明瞭に示寸ことが目 的であり, 2 次元計算に限定し 3 次元の計算は敢えて実施 しなかったが，その拡張は計算時間の増大以外の困難は ないと考えている. 土砂粒子は流れのせん断応力が強い 場合, 粒径が減少するモデルも報告されており, その導 入について検討したい. また, $\sigma$ 座標では格子の直交性を 損なう計算方法は水塊内部を浮遊する土砂輸送の理解の 

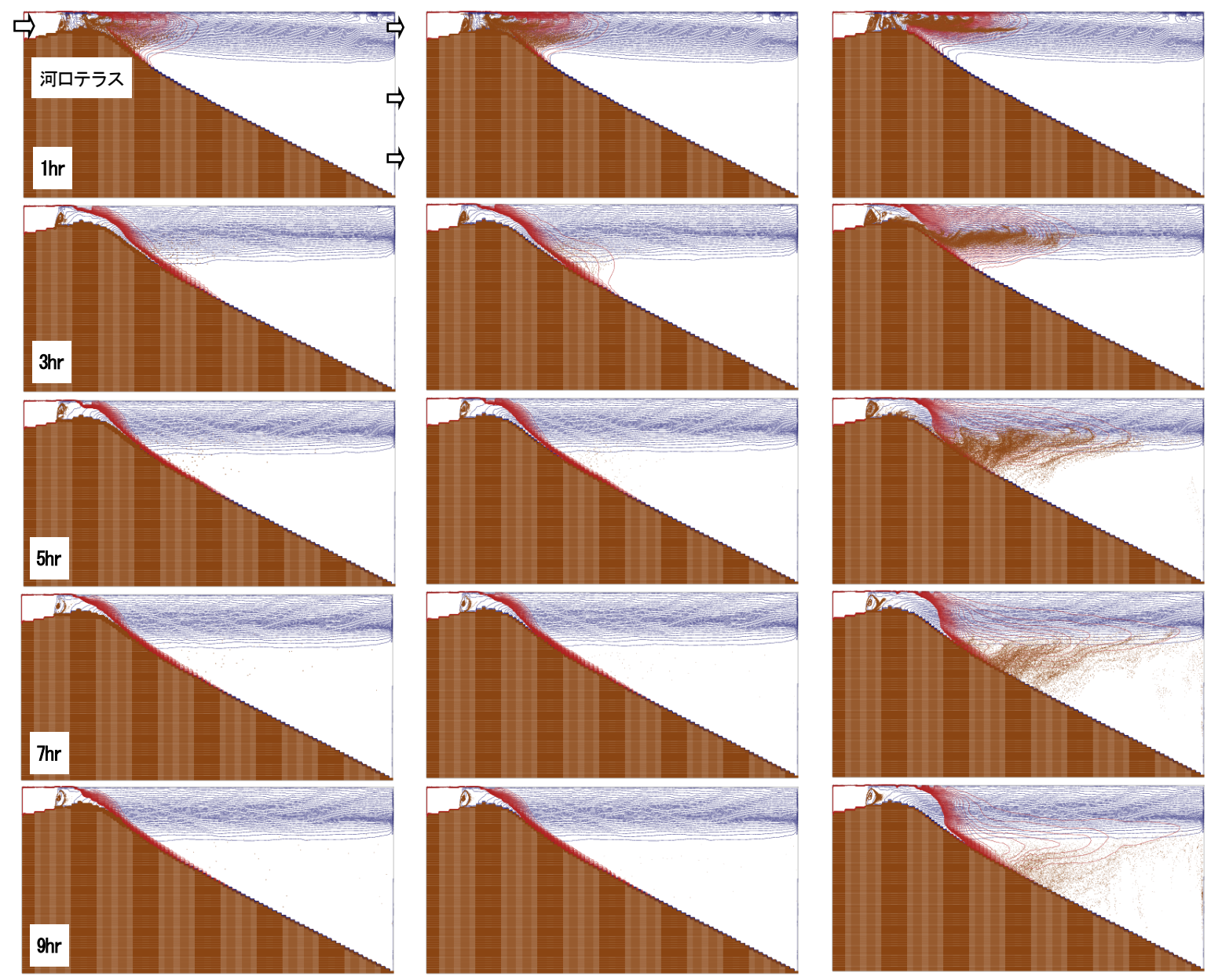

図-7 大河津分水路河口付近の土砂、密度、土砂粒子の分布の時間変化（時間差:2 時間）

左 $w s=0.09 \mathrm{~cm} / \mathrm{s}, D=54.4 \sim 4 \mu \mathrm{m}$ ， 中 $w s=0.07 \mathrm{~cm} / \mathrm{s}, D=32.0 \sim 4 \mu \mathrm{m}$, 右 $w s=0.02 \mathrm{~cm} / \mathrm{s}, D=12.0 \sim 4 \mu \mathrm{m}$

妨げとなるため，今回は考慮しなかった。しかし、土砂 が海底面に着底する部分に注目する場合は考慮する必要 がある.さらに，今回は定性的な評価しか行えなかった ため，今後は定量的な評価の方法を検討していくことと したい.

謝辞 : 本研究を遂行するにあたり，地形および流量デー タの使用に関して便宜を図って頂いた，国土交通省北陸 地方整備局信濃川河川事務所の関係各位に謝意を表す. 河口における土砂の輸送過程の数值計算方法について助 言を頂いた大阪市立大学理学研究科客員教授関口秀雄先 生に深甚なる謝意を表す. 本研究は科学研究費補助金 (基 盤研究(B), No. 2 3360206, No. 26289155 研究代表者 : 関 口秀雄 ）のサポートを受けた.

\section{参考文献}

1) 関口秀雄, 山崎秀夫, 中川亮太, 石田真展, 東 良慶, 原口 強, 細山田得三: 河口砂浜海岸の堆積環境变遷における洪水土砂 流出の重要性, 土木学会論文集 B2 (海岸工学), Vol.69, No.2, pp. I_691-I_695, 2013.

2）細山田得三，早川典夫，青山了士，J. F. Atkinson, 福嶋祐 介: 河口における密度流と浮遊物質の輸送に関する数值計算,
水工学論文集, 第 45 巻, pp.955-960, 2001.

3）柳 哲雄 : 沿岸海洋学-海の中でものはどう動くか, 恒星社厚 生閣, 1989.

4）宋 元平，小田一紀，重松孝昌，汪 思明 : 河口域における 密度流形態と最大混濁帯の 2 次元数值シミュレーション, 海 岸工学論文集, 第46 巻, pp.471-475, 1999.

5）伊勢屋ふじこ：沈降式粒度分析の手引き，筑波大学水理実験 センター報告, No.9, pp.115-128, 1895.

6）島田友典, 渡邊康玄 : 2003 年 8 月洪水において二風谷ダム 湖に堆積した微細粒子の沈降・浮上速度, 土木学会北海道支 部論文報告集, 第61 号,pp.139-142, 2005.

7）鶴谷広一，村上和男，入江功 : 多層レベルモデルによ る航路埋没の予測計算, 海岸工学論文集, Vol.36, pp379-383. 1989.

8) C. W. Hirt, B. D. Nichols, N. C. , Romero : SOLA - A Numerical Solution Algorithm for Transient Fluid Flows, Los Alamos Scientific Laboratory LA-5852, pp1-50, 1975.

9）池畑義人, 本地弘之 : 安定成層流体中に水平に流入する負の 浮力をもつ噴流の LES モデルによる解析, 日本流体力学会 誌「ながれ」, Vol.19, No.5, 2000.

(2015. 9. 30 受付) 